\title{
Working
}

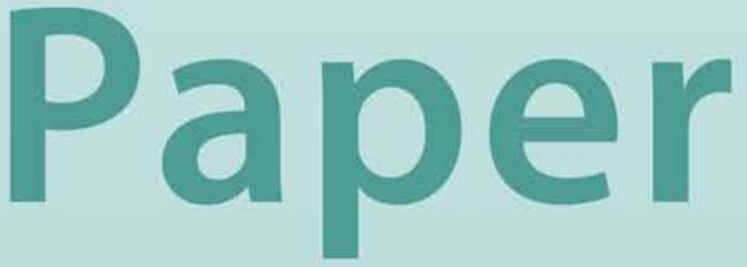




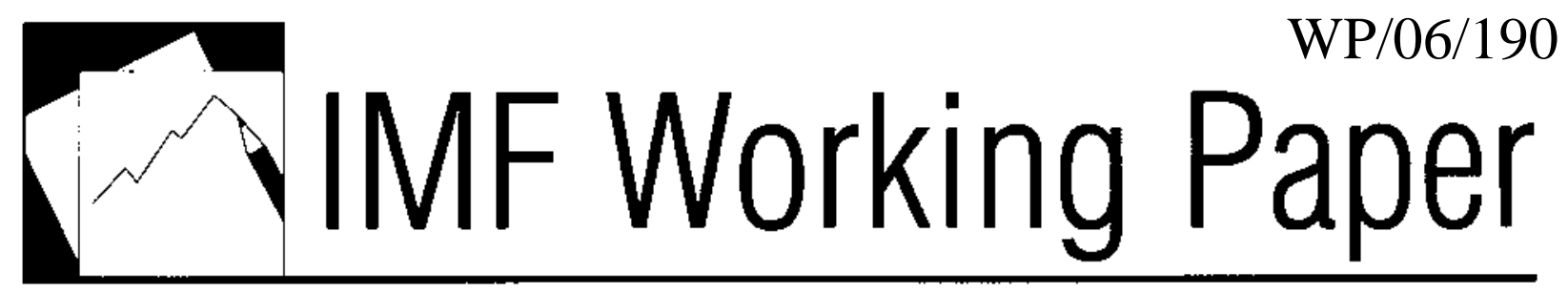

What's Driving Private Investment in Malaysia? Aggregate Trends and Firm-Level Evidence Roberto Guimaraes and Olaf Unteroberdoerster 


\title{
IMF Working Paper
}

Asia and Pacific Department

\section{What's Driving Private Investment in Malaysia? Aggregate Trends and Firm-Level Evidence}

\section{Prepared by Roberto Guimaraes and Olaf Unteroberdoerster ${ }^{1}$}

Authorized for distribution by Shogo Ishii

August 2006

\begin{abstract}

\section{This Working Paper should not be reported as representing the views of the IMF.} The views expressed in this Working Paper are those of the author(s) and do not necessarily represent those of the IMF or IMF policy. Working Papers describe research in progress by the author(s) and are published to elicit comments and to further debate.

Private sector investment has been a key source of growth in Malaysia over the last three decades, but after an unprecedented decline in the wake of the Asian crisis it has remained sluggish in recent years. Using aggregate and firm-level data, this paper aims to explain these trends and their implications for Malaysia's investment and growth outlook. Aggregate data point to sustained overinvestment in the years prior to the Asian crisis and the role of shifts in investor perceptions as important determinants of the recent decline in private investment. Meanwhile, firm-level data suggest that low profitability, along with financing constraints affecting smaller firms and those in the services sector, has also been important.
\end{abstract}

JEL Classification Numbers: D21, E22, E32

Keywords: Private investment, long- and short-run dynamics, Tobin’s Q, corporate investment, panel data analysis

Author(s) E-Mail Address: rguimaraes@imf.org; ounteroberdoerster@imf.org

\footnotetext{
${ }^{1}$ We thank, without implications, Irena Asmundson, Shogo Ishii, Charlie Kramer, Laura Papi, Rodney Ramcharan, Reza Siregar, and participants at a seminar in Putrajaya (Malaysia) for helpful comments and suggestions.
} 


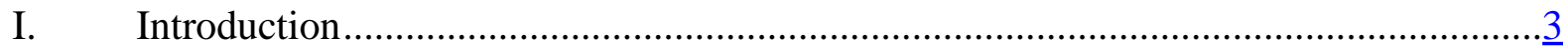

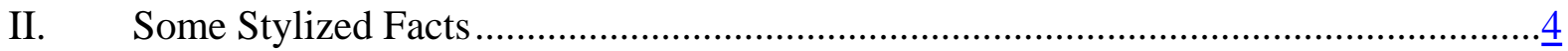

III. Determinants of Private Investment..................................................................

A. Aggregate Trends .......................................................................................

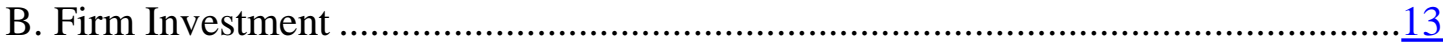

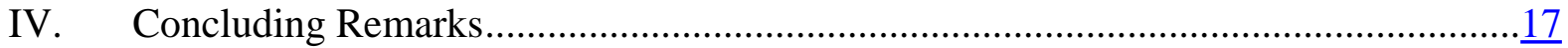

Tables

1. Nonfinancial Corporate Sector Soundness Indicators, 1995-2004 ..........................19

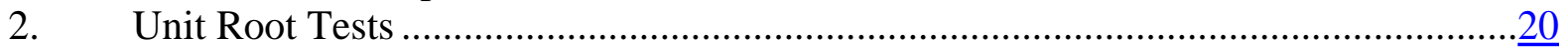

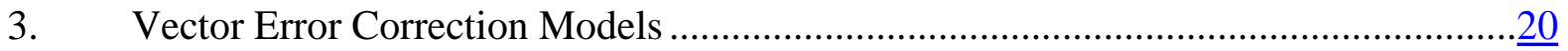

4. Investment Equation ...................................................................................

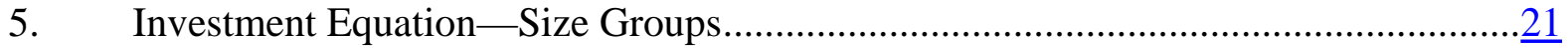

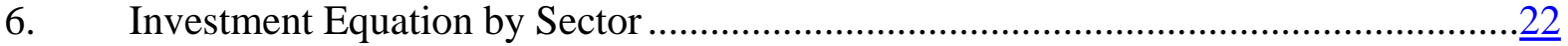

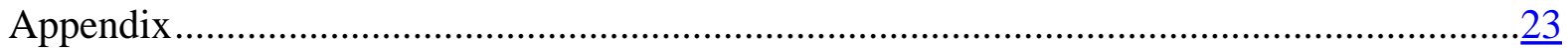

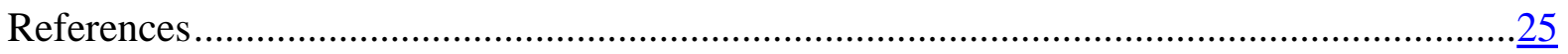

Figures

1. Aggregate Investment Ratio in East Asian Emerging Markets .................................. $\underline{5}$

2. Investment Trends in Selected Asian Emerging Markets.......................................... $\underline{5}$ 


\section{INTRODUCTION}

In the wake of the Asian financial crisis, Malaysia experienced an unprecedented decline in private sector investment. After rising steadily between 1987 and 1997 to over 30 percent of GDP, private investment collapsed and only began to stage a gradual recovery in 2004. At about 10 percent of GDP in 2005, however, it still remains substantially below precrisis levels. With the decline in private investment and a relatively stable savings rate, Malaysia's current account has shifted from a deficit to a substantial and widening surplus since the late 1990s.

This paper's main focus is to explain Malaysia's investment trends and their implications for growth. Conclusions drawn for the scope of promoting a recovery in private investment may also be relevant for other countries in the region that have suffered a private investment slump in recent years. To the extent that large current account surpluses in emerging Asia reflect this broader investment slump, the analysis would also be relevant for the adjustment of global imbalances.

The paper analyses macroeconomic trends, particularly the relationship between real output growth and investment, and firm-level data, focusing on the relationship between firm characteristics and investment. Using a relatively long time series of aggregate private investment permits a more formal assessment of long- and short-run determinants and deviations of private investment from its fundamentals, helping identify periods of (under)overinvestment. In part reflecting data constraints, however, the effect of certain factors, especially those related to the health of the corporate sector, is difficult to capture at the aggregate level. Therefore, we also employ firm-level data to shed light on the role of corporate profitability, potential financing constraints, and to assess differences in investment behavior across sectors of the economy.

Our main findings include: (1) in the long run, the level of private investment in Malaysia has been closely related to real GDP, but there is evidence of sustained overinvestment, in particular in the property sector, in the years leading to the Asian crisis; (2) private investment is thus unlikely - and unnecessary from a growth perspective- to return to precrisis levels; (3) besides macroeconomic conditions, a shift in investors' perceptions, which may have been triggered by the crisis itself or by prolonged overinvestment, appears to have contributed to the sharp decline in private investment in recent years; (4) at the firm level, profitability is the main determinant of investment in Malaysia across all sectors; and, (5) while firm size also generally matters, other factors, notably financing constraints, seem to affect investment, in particular for smaller firms and those in the services sector.

The remainder of the paper is organized as follows. The next section will present key stylized facts on aggregate investment behavior, including evidence on overinvestment, the role of corporate profitability, and sectoral investment patterns. This is followed by the application of a vector error correction and panel data analysis of aggregate and firm investment behavior, respectively. The empirical models are rooted in the neoclassical theories of 
aggregate and firm investment, but also aim to include factors that might arise from market imperfections. The final section will offer some concluding remarks and policy implications.

\section{SOME STYLIZED FACTS}

Over the last 30 years, total investment in Malaysia, and East Asian emerging markets more generally, has been characterized by large swings. On average, total gross fixed capital formation in these countries rose steadily from under 20 percent of GDP in the early 1970s to over 25 percent of GDP in the mid-1980s, and after a marked decline around 1986, rose again to peak at over 30 percent of GDP prior to the Asian financial crisis (Figure 1). ${ }^{2}$ Investment declined to a prolonged trough of around 23 percent of GDP in the early 2000s. In Malaysia, total investment peaked at about 40 percent of GDP in the early 1980s and then again prior to the Asian financial crisis. The current investment trough, at about 20 percent of GDP, is only marginally lower than the previous one (circa 1988), but much more prolonged. Similar swings are observed in Korea and Thailand, the main comparator countries for the purpose of this paper, although in both countries the investment recovery since the Asian crisis has been quicker (Figure 2).

Domestic private investment has been the main driver of these trends, and its sharp decline in the wake of the Asian financial crisis has been unprecedented, particularly for Korea, Malaysia and Thailand. Similarly, record investment prior to the crisis in these countries coincides with a surge of private investment. However, one exception is Malaysia's first investment boom in the mid-1980s, which was in part driven by a large increase in public investment projects. In all three countries, public investment has tended to play a relatively greater role after the crisis, partly offsetting the collapse of private investment.

By contrast, foreign direct investment (FDI) has played only a limited role in explaining recent sluggish private investment trends in Asia. For most emerging Asian countries, FDI is a relatively small part of total investment. ${ }^{3}$ Moreover, in U.S. dollar terms, average annual FDI inflows in the precrisis years and the postcrisis years are virtually unchanged for several Asian emerging markets, while they

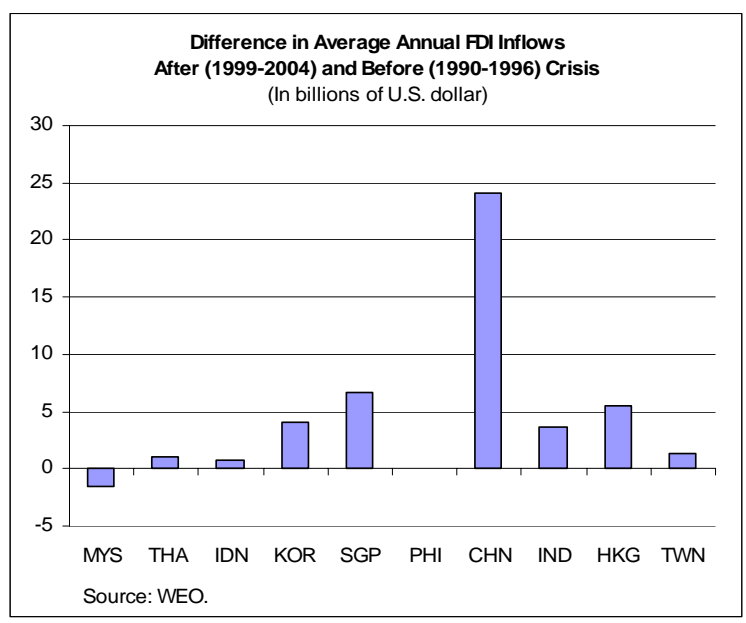

${ }^{2}$ Emerging East Asia includes: Hong Kong SAR, Indonesia, Korea, Malaysia, Philippines, Singapore, Thailand, and Taiwan Province of China.

${ }^{3}$ Except for Singapore, inward FDI into each country averaged less than 15 percent of total gross fixed capital formation over the last two decades. 
Figure 1. Aggregate Investment Ratio in East Asian Emerging Markets 1/ (Gross fixed capital formation as percent of GDP)

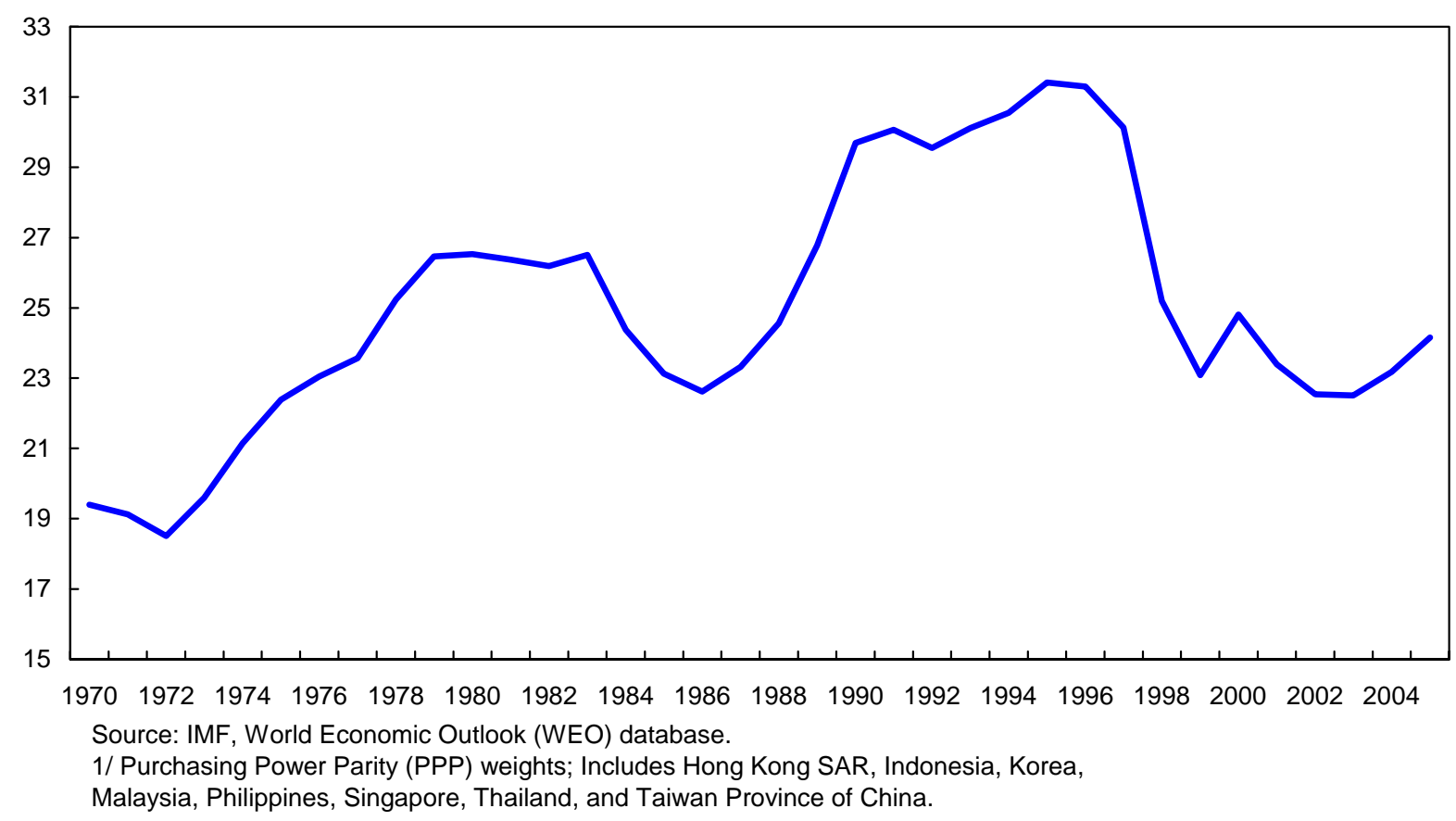

Figure 2. Investment Trends in Selected Asian Emerging Markets (Gross fixed capital formation in percent of GDP)

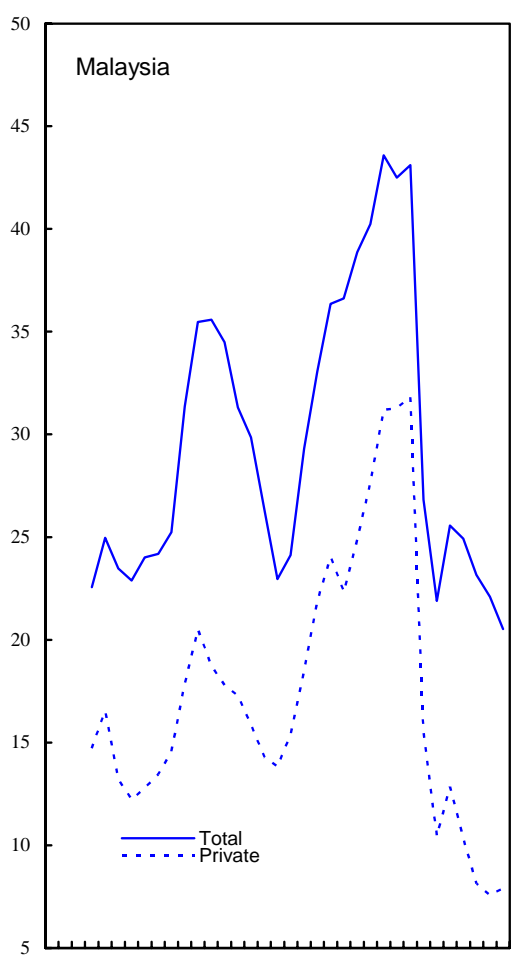

707274767880828486889092949698000204 Sources: WEO; WDI; CEIC.

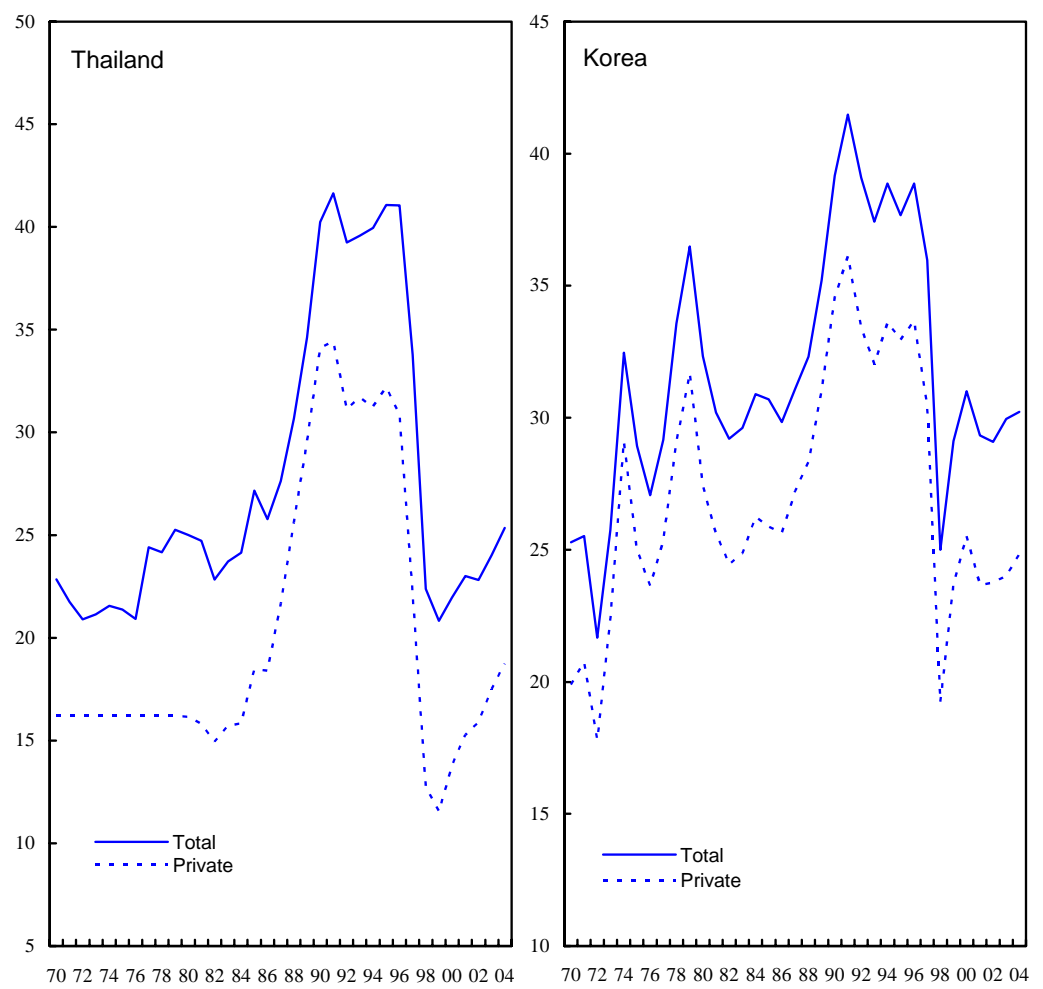


continued to rise noticeably for Korea, Singapore, and Hong Kong SAR. Only Malaysia records a small decline, but in relation to GDP this trend began already in the early 1990s. China stands out with a sharp increase in FDI inflows, but evidence of an FDI diversion from other Asian countries into China in recent years is inconclusive. ${ }^{4}$

In Malaysia, overinvestment in the property sector appears to have played an important role in the marked boom and bust cycle of private investment of the last decade. ${ }^{5}$ First, the real growth rate of property loans, which peaked at 30 percent per year during 1996-98, turned negative in 1999 and has remained substantially lower at about 5-10 percent per year since 2000. Similarly, the consumer price index for gross rent, which rose on average by 3-4 percent per year prior to 1998, has risen by 1 percent per year since. Comparing housing prices directly, it is also noteworthy that Malaysia's housing price index rose faster than in Thailand and Korea prior to the crisis and then registered the sharpest decline. ${ }^{6}$ As for commercial property, a trend decline in hotel occupancy rates during the 1990s also points to unsustainable investment levels.

Firm-level data for Malaysia confirm the

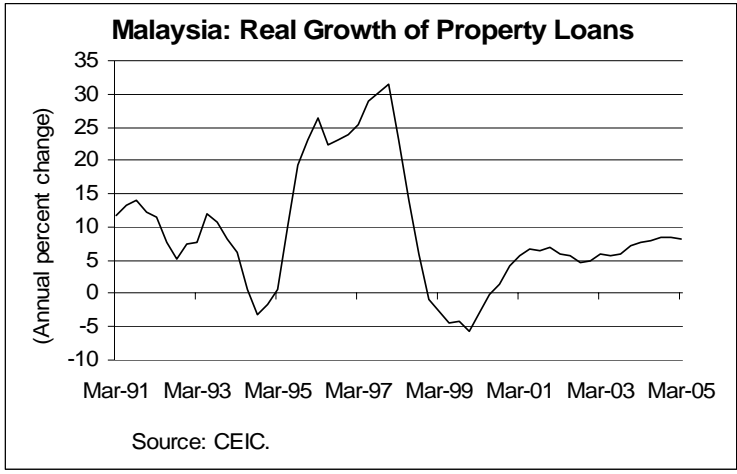
private investment trend observed in the

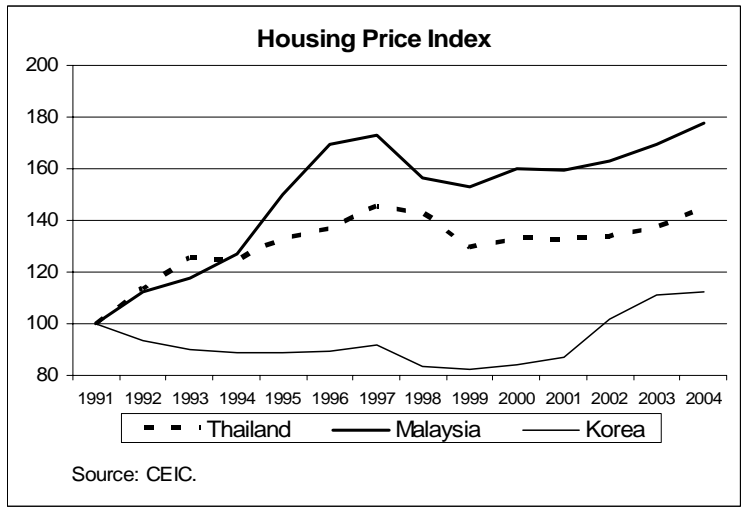
aggregate data discussed above, but suggest that the recent decline of private investment was more broad based. ${ }^{7}$ The corporate data used in this paper include all Malaysian listed nonfinancial firms covered in the WorldScope database during the period 1995-2004. Many of these firms entered the data set after 1995, implying shorter series for them. Firms that

${ }^{4}$ Contrary to other studies, Mercereau (2004) argues for normalizing measures of FDI and concludes, broadly, that China's FDI flows do not have much impact on FDI flows to other countries.

${ }^{5}$ Malaysian national accounts data do not provide sectoral detail on private investment. Because of these limitations the discussion here focuses on indirect indicators of investment activity.

${ }^{6}$ For an analysis of property price bubbles in the Asian crisis countries, see Collyns and Senhadji (2002).

${ }^{7}$ While there are conceptual differences in the computation of investment in the two data sets, it is noteworthy that the corporate data seem representative of the investment dynamics observed at the macroeconomic level. The main conceptual differences refer to: (1) accrual nature of national accounts data versus cash basis of firmlevel corporate investment, and (2) the fact that firm-level investment is typically normalized by the firms' fixed assets (as in the case of the Worldscope database). 
exited before 2004 are not included. ${ }^{8}$ The data are grouped into five major sectors of activity. Those include (number of companies as of 2004): basic and general industries (391), services (104), utilities, resources, and conglomerates (URC, 31), information technology (60), and consumer goods (180). Government-linked companies (GLCs) are featured prominently in the URC sector. The investment behavior of the sample firms shows that investment declined substantially following the Asian crisis and only recovered slightly in 2003-04.

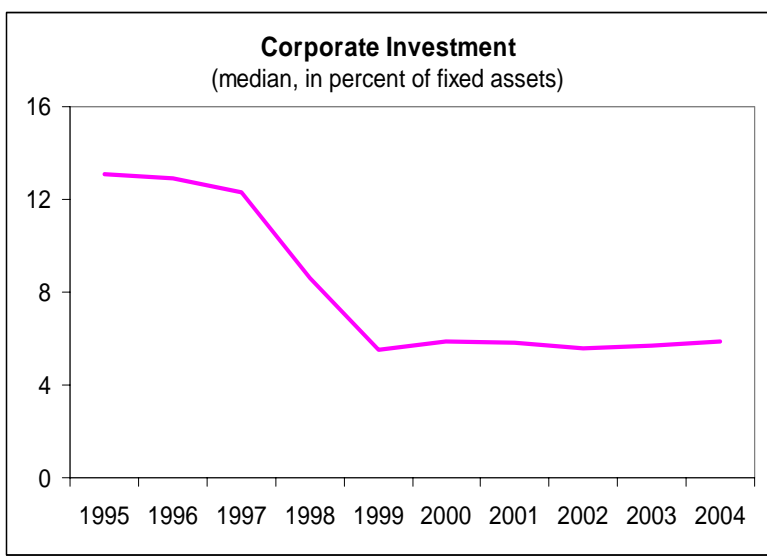

This decline in investment is mirrored by the slump in corporate profitability and market valuation indicators during the 1995-2004 period. The firm level data show a broad based decline in profitability during most of the sample period. In addition, despite the increase in 2003-04, profitability indicators remain low, including by regional comparison. Both the return on equity (ROE) and the return on assets (ROA) have been lower than the average of emerging market economies in the region since 1997. A similar trend is observed for Tobin's $\mathrm{Q}$, measured as the ratio of market capitalization plus the book value of debt to total market value of assets, indicating that market participants expect profitability of Malaysia's corporate sector to remain relatively weak. ${ }^{9}$
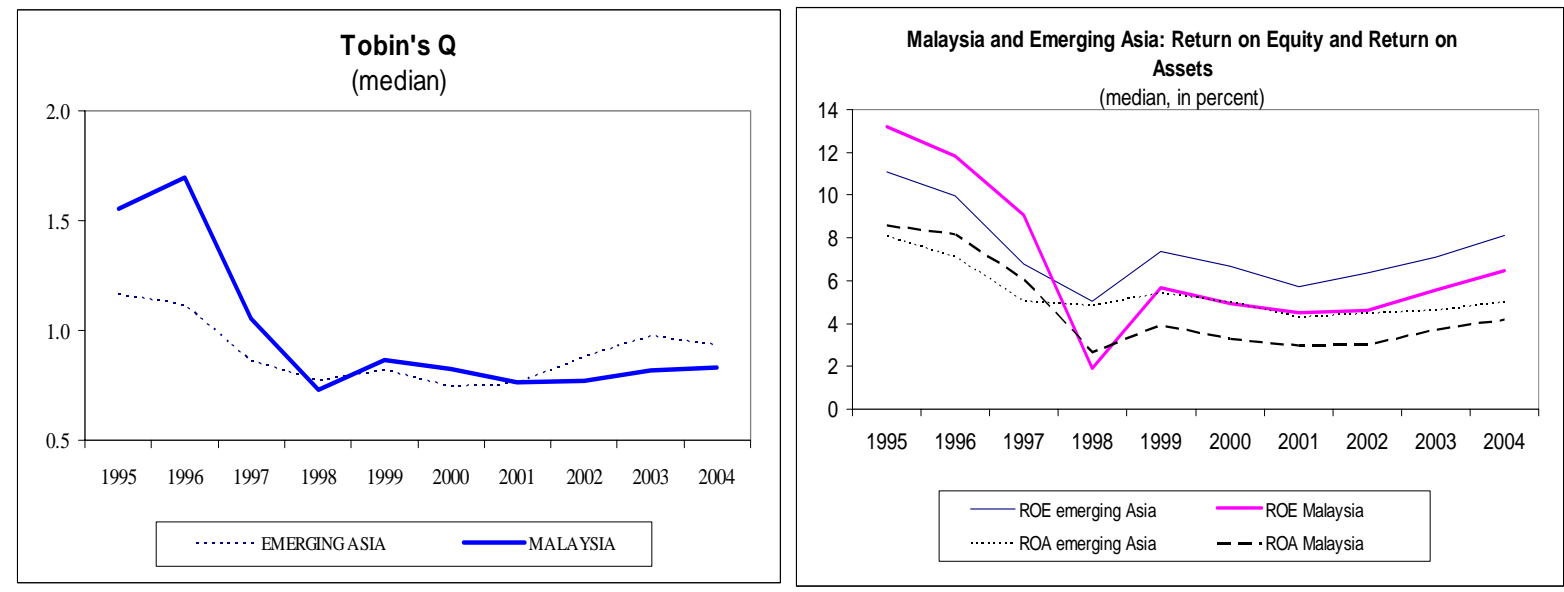

\footnotetext{
${ }^{8}$ This "survivorship bias" in the data is known to introduce problems for tests of asset pricing models, but not for tests of the investment model.

${ }^{9}$ Alternative measures of Tobin's Q, including the ratio of the value of assets plus market value of equity minus book value of equity over book value of assets, yield virtually identical results.
} 
In contrast with the profitability indicators, corporate sector soundness has improved substantially in Malaysia in recent years (Table 1). Corporate leverage has decreased markedly since 1999, with the debt to equity (assets) ratio declining by more than 20 (7) percentage points between $1998-2004 .^{10}$ Moreover, liquidity indicators_-including the current ratio (current assets to current liabilities), the quick ratio (cash and receivables to current liabilities), and the interest coverage ratio (earnings to interest expenses)—-have all improved. These improvements reflect financial restructuring following the Asian crisis and recent favorable economic conditions.

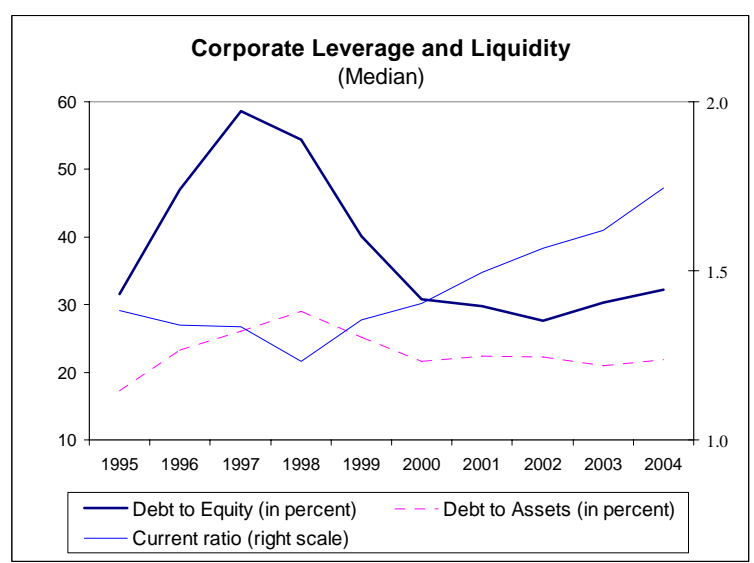

The behavior of investment displays a broadly similar pattern across all five sectors studied. With the exception of information technology (IT), the other sectors show a sizable decline in investment after 1998, with a small recovery taking place in 2004 . In the case of IT, there is an additional big drop following the burst of the technology bubble in the United States in 2000-01. The behavior of Tobin's Q and ROA also displays strong comovement across sectors. All sectors experienced a sharp decline in the profitability and Tobin's Q during the Asian crisis, followed, with the exception of the more volatile IT sector, by relatively stable but generally low profitability since then. In some

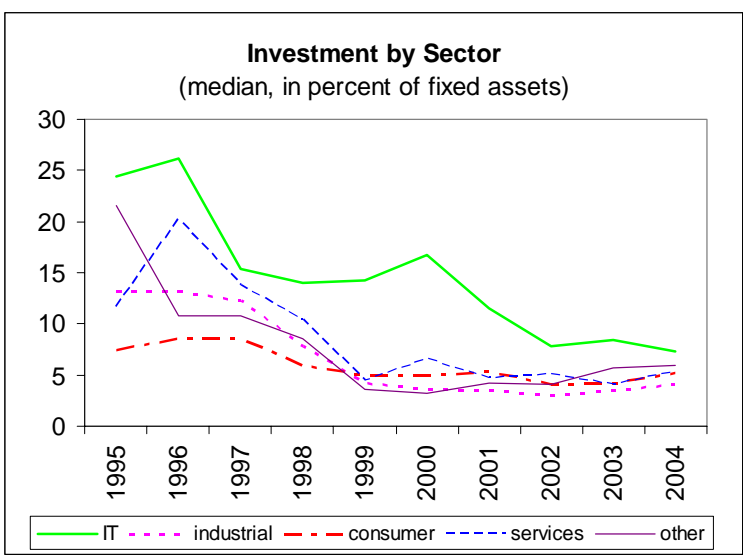
cases, a modest recovery has taken place during 2002-04. The industrial and service sectors, which account for about half the number of firms in the sample, have had the lowest profitability since the crisis.

\footnotetext{
${ }^{10}$ Since the debt to asset ratio has been broadly stable in the last couple of years, the slight increase in the debt to equity ratio in 2003-04 is consistent with an asset build in the same period.
} 

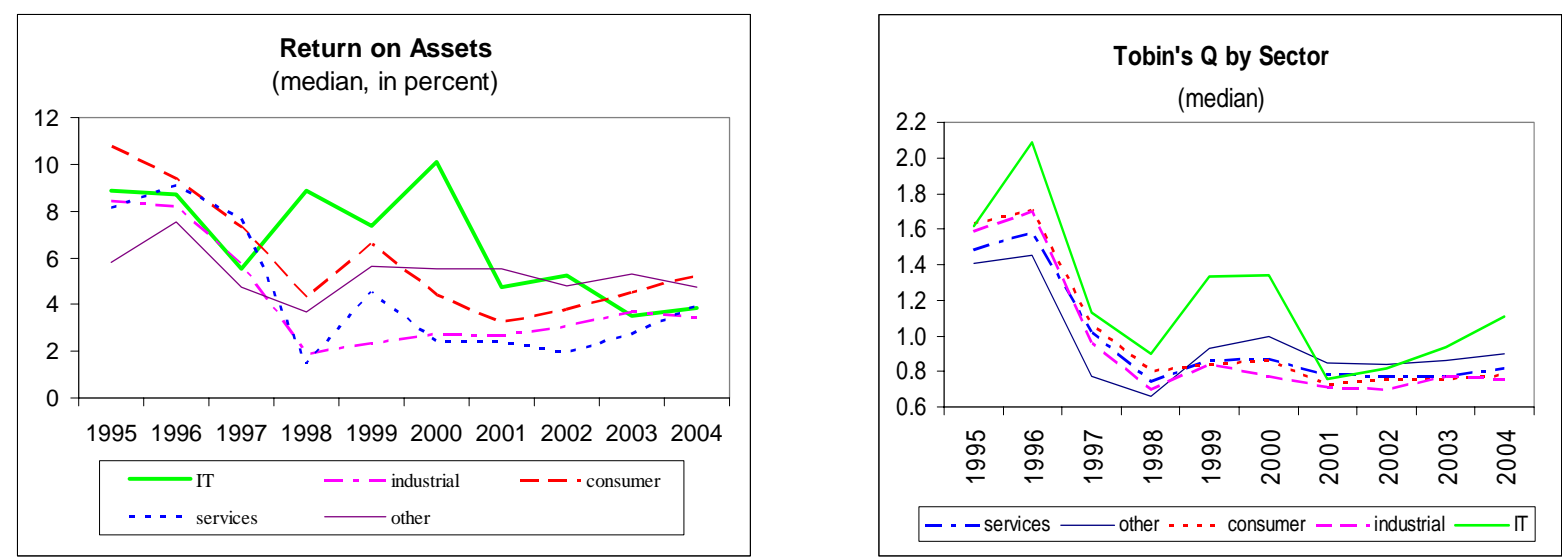

III. Determinants of Private InVEstment

\section{A. Aggregate Trends}

To provide a quantitative assessment of the determinants of private investment in Malaysia in the short and long run, we start from a simple conceptual framework that is anchored in the neoclassical theory of investment. ${ }^{11}$ As shown in Jorgenson (1971), in the long-run equilibrium, there is a stable relationship between an economy's capital stock, the level of real output and the real user cost of capital. Assuming constant rates of depreciation and real growth in the steady state, there should also be a long-run relationship between gross investment, output and the cost of capital (Pelgrin et al. 2002). It should be noted at the outset, however, that estimating and interpreting even such a simple benchmark model for Malaysia is subject to data limitations. Specifically:

- With no quarterly data on private fixed capital formation available, and annual data only spanning the period 1973-2004, empirical results need to be interpreted with caution. Moreover, various IMF staff reports indicate that official data for 1973-85 were repeatedly revised, suggesting measurement problems. ${ }^{12}$

- In the absence of long time series of long-term interest rates, average real bank lending rates are used as a proxy for capital cost. ${ }^{13}$ This data series is adjusted by

\footnotetext{
${ }^{11}$ For other country examples in the empirical literature, see Akkina and Celebi (2002) on Turkey, Kannapiran (2001) on Papua New Guinea, Naqvi (2002) on Pakistan, Oshikoya (1994) on selected African countries, Pelgrin et al. (2002) for OECD countries, and Song et al. (2001) on China.

${ }^{12}$ Official data on private investment are derived indirectly from statistics on total investment and public sector spending.

${ }^{13}$ Annual data on five-year government bonds are only available from 1993.
} 
the ratio of the investment deflator to the GDP-deflator to account for relative changes in capital cost (Pelgrin et al, 2002). Yet, such an adjustment does not take into account quality improvements of investment goods over time, nor any tax factors that affect the cost of capital. Regulations on lending rates (e.g., interest rate ceilings) may also distort this measure.

The basic model is augmented by a number of other determinants that could arise from market imperfections or might reflect cost and return factors otherwise not captured in the baseline model. These include: ${ }^{14}$

- Financial development and availability of financing: This is proxied by two variables, the ratio of private sector credit to GDP, or the ratio of stock market capitalization to GDP. More developed financial systems tend to lower the cost of intermediation and thus facilitate investment.

- Public investment: Public investment could crowd out private investment through increased borrowing and higher tax burden in the future or promote and complement it, to the extent that investments in infrastructure helps raise the productivity of the private sector.

- Exchange rate volatility: Exchange rate volatility may capture two effects: (1) the overall role of macroeconomic stability providing an environment conducive for investment; ${ }^{15}$ or (2) the role of exchange rate risks as a direct investment risk.

Based on the above considerations, the following vector-error correction model is estimated:

$$
\begin{aligned}
\Delta I_{t} & =\mu+\sum_{i}^{p} a_{i} \Delta I_{t-i}+\sum_{i}^{p} b_{i} \Delta Y_{t-i}+c Z+d\left(I_{t-1}-c-Y_{t-1}\right)+\varepsilon_{t} \\
\Delta Y_{t} & =\ldots,
\end{aligned}
$$

where $\mathrm{Z}$ represents a vector of the above variables in the short-run (in first differences for nonstationary variables), and $d$ the adjustment coefficients to deviations from a long-term relationship determining investment (I), measured as real private fixed capital formation. A stable and statistically significant long-run relationship is only found with real output (Y). ${ }^{16}$ The main results for different specifications are summarized in Table 3.

\footnotetext{
${ }^{14}$ For an overview of theoretical considerations concerning these variables see Ghura and Goodwin (2000).

${ }^{15}$ In some studies, this is also captured by controlling for periods of high inflation.

${ }^{16}$ Johansen cointegration tests are conducted for all nonstationary I(1) variables (see Table 2), i.e., private investment, real output, public investment, and stock market capitalization. The coefficients on public investment and market capitalization are found not to be statistically significant. Dynamic OLS and the PhillipsHansen fully modified OLS estimator confirm this result.
} 
- $\quad$ Output growth translates one-to-one into private investment in the long run and this relationship is fairly robust to the inclusion of different short-run factors. ${ }^{17}$ The negative adjustment coefficient on the error correction term in most model specifications also suggests that private investment tends to return to this long-run relationship. The model thus confirms that the decline in investment following the Asian crisis in part reflects overinvestment prior to the crisis. Calculations based on the model specification in Table 3, column 1, suggest that there was significant private overinvestment of more than 10 percent of GDP per year for about four years prior to 1998.

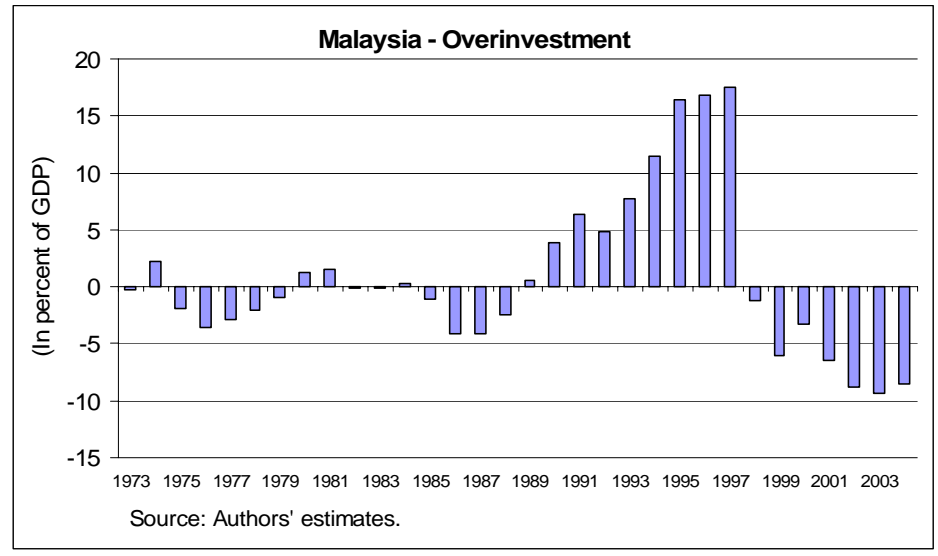

- However, with the coefficient on the error-correction term estimated to be small, below $0.1-0.17$ in most cases, adjustment takes about 6-10 years and periods of over- and underinvestment can be sustained. The apparent difficulty in achieving a timely restructuring may reflect that excess investment has been concentrated in the property sector as described above. An overhang in the capital stock here may well persist longer than in other sectors, in particular manufacturing, where machinery is continuously being replaced by newer vintage equipment and has a shorter life cycle.

- $\quad$ Real growth also has a statistically significant impact in the short run, with 1 percent higher growth leading to between 2-4 percent higher investment. The contractionary effect of the Asian financial crisis, leading to a decline in real growth of 7 percent in 1998, could thus have contributed to a fall in private investment of up to 30 percent. Similarly, a favorable external environment and robust growth since 2003 have supported the recent recovery in private investment.

- $\quad$ Apart from growth, the single biggest short-run impact stems from an Asian-crisis dummy, which is statistically significant and negative in all specifications. The measured coefficient of the crisis dummy, consistently above 0.7 , implies that the crisis itself, ceteris paribus, caused private investment levels to drop by half. The dummy may account primarily for the heightened uncertainty, ${ }^{18}$ a shift in investor sentiment reflecting a prolonged period of overinvestment, including in the property sector, and a worsening of investors' perception of governance. With regard to the latter, investor

\footnotetext{
${ }^{17}$ This is in line with findings by Pelgrin et al. (2002) for a set of OECD countries.

${ }^{18}$ In Malaysia, the ratio of real output growth to its standard deviation dropped from 7.6 (1994-97 average) to 1.8 (2000-05 average).
} 
perceptions of political stability, regulatory quality, and the rule of law, appear to have worsened significantly at the time of the crisis. Compared with Korea and Thailand, where indicators recovered somewhat between 1998 and 2000, the drop in investor perceptions on governance was stronger and more protracted in Malaysia, which may help explain the relatively slow recovery of private investment. It is also noteworthy that a dummy to account for Malaysia's 1985 recession, the only other recession in the period of observation, is not found to be statistically significant from zero. This underscores that additional factors, other than the usual determinants of investment, were at play in 1998.
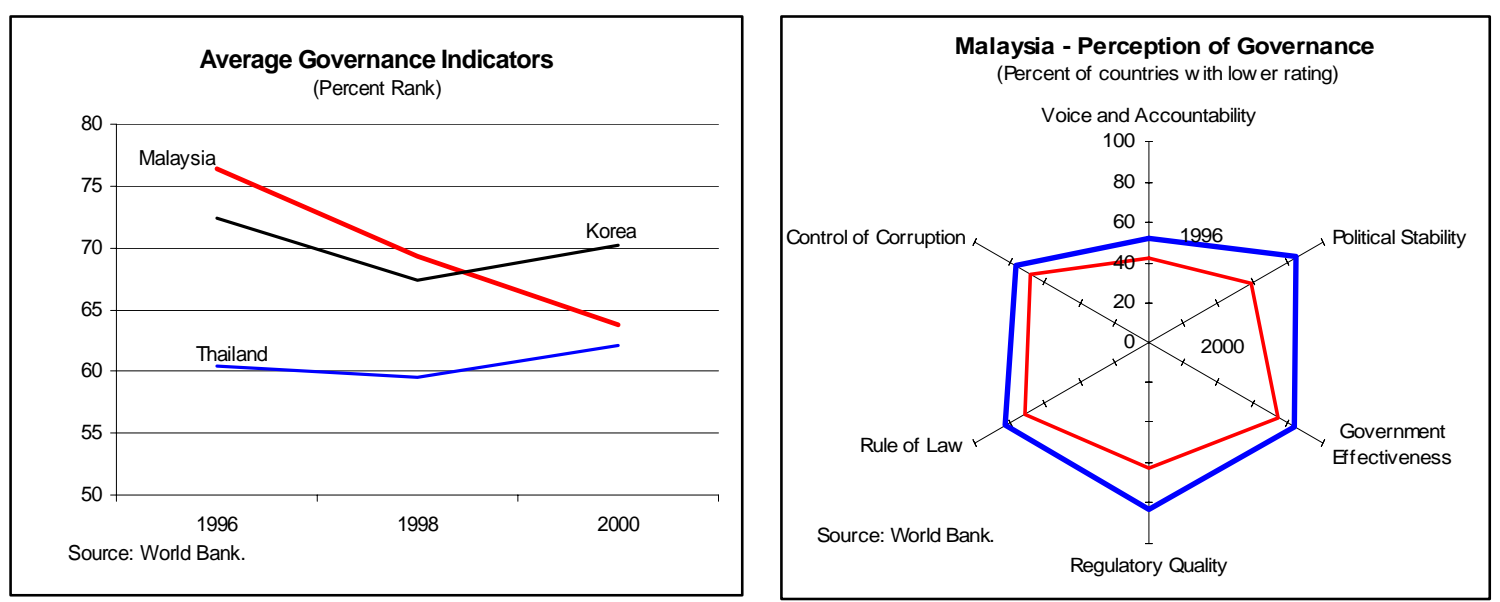

- Exchange rate volatility is not found to have a statistically significant impact on shortrun investment growth as long as the crisis dummy is included. ${ }^{19}$ This suggests that the moderate exchange rate uncertainty experienced for most of the period did not affect private investment, while heightened volatility in 1998 was as much a result of the crisis as was the collapse of private investment in that year. The lack of evidence of a link between exchange rate volatility and investment may also reflect the declining importance of FDI, which could be relatively more exposed to exchange-rate risk, in overall investment as described above, or, an ambiguous theoretical relationship (see for example, Nicolas, 2004).

\footnotetext{
${ }^{19}$ Exchange rate volatility in Table 3 is measured as the standard deviation of monthly ringgit-U.S. dollar exchange rate changes. The results also hold if the nominal effective exchange rate is used.
} 
- The results do not clearly support that capital cost has a negative short-run impact on the growth rate of private investment. However, this needs to be interpreted with caution, given the measurement problems mentioned above and that including capital cost makes the coefficient on the error term statistically insignificant, pointing to problems with model specification. ${ }^{20}$ Nevertheless, the

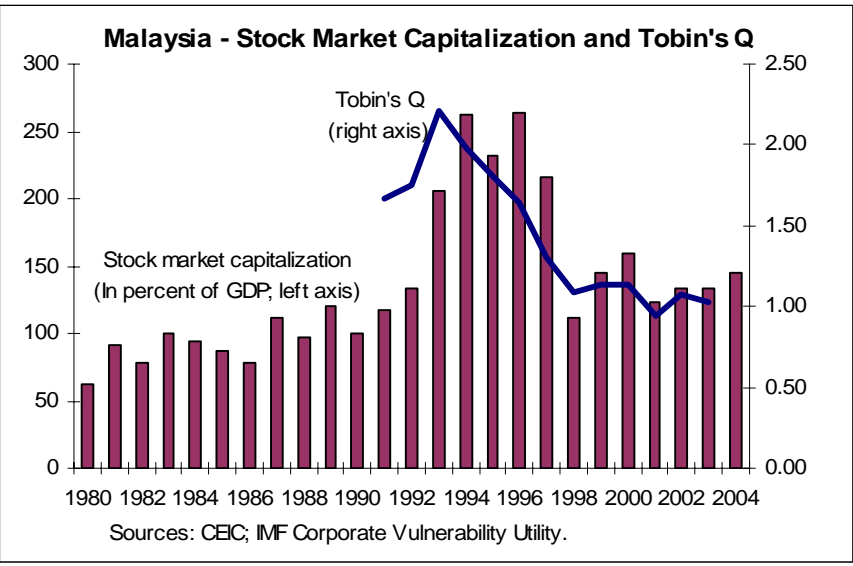
impact of capital cost may also be captured by a substantial decline in Tobin's Q (the ratio of the market to the book value of assets), although limited data availability of Tobin's Q for the years 1991-2003 only precludes inclusion in the regression analysis. In this light, the slump in private investment after the Asian financial crisis could reflect a sharp increase in the relative cost of equity (see firm-level analysis below).

- There is no firm evidence that availability of financing has a short-run impact on investment growth at the aggregate level, both when measured as an increase in the ratio of market capitalization or credit to GDP. For market capitalization, which collapsed at the same time as private investment during the Asian crisis, this may reflect the short period of observation (1980-2004).

- Higher growth in public investment is not found to have a statistically significant shortrun impact on private investment.

\section{B. Firm Investment}

While the aggregate investment model highlights the role of growth and shifts in investor sentiment, evidence on capital cost and the availability of financing is inconclusive, probably in part reflecting data constraints. However, as the stylized firm-level data reveal, the recent decline in investment coincided with weakening profitability across all sectors, even as corporate leverage and liquidity indicators improved. To formally assess how much firmlevel determinants matter and assess their impact across industries, this section applies a standard model of corporate investment to the sample of Malaysian firms. According to the neoclassical model of firm investment behavior, a company's investment depends solely on its expected future profitability, usually proxied by Tobin's Q (Hubbard, 1998 and Appendix I). In general, corporate investment may also depend on other factors, including sales and

\footnotetext{
${ }^{20}$ This difficulty in capturing a significant impact of capital cost on investment at the aggregate level is well documented in the empirical literature, which prompted researchers to turn to industry- or firm-level data to investigate the impact of capital cost.
} 
availability of funds. Therefore, the investment model estimated here can be expressed as follows:

$$
(I / K)_{i, t}=\alpha_{i}+\beta Q_{i, t}+\gamma^{\prime} Z_{i, t}+\varepsilon_{i, t}
$$

where I/K is the investment to fixed assets ratio, $\mathrm{Q}$ is Tobin's $\mathrm{Q}$, and $\mathrm{Z}$ is a vector of the following firm-specific variables: ${ }^{21}$

- $\quad$ sales, which reflect the accelerator effect, since an increase in sales (signaling more demand for a firm's output) could lead to an increase in investment;

- cash flow, which measures internal funds available to finance investment projects; cash flow may also be considered a proxy for current profitability;

- stock of liquid assets (including cash), which can be used to finance investment projects;

- leverage (measured by the debt-to-asset ratio), which captures the effect of financial restructuring on investment; and

- firm size, which typically controls for other firm characteristics that may be potentially important for investment.

Two approaches are used to control for the differences across sectors. First, in random effects and pooled least squares estimations, sectoral dummies are included in the regression. In the case of fixed effect (FE) estimations, separate FE estimations are run for each sector. The latter approach also has the advantage of allowing the effect of each regressor on investment to vary across sectors. The results reported are based on FE estimations as standard specification tests (Haussman-Wu and Breusch-Pagan) typically reject random effects specification at the 5 percent level. It should also be noted that outliers are excluded from the empirical analysis. In particular, each variable is trimmed based on its own average and standard deviation (points more than two standard deviations away from the average on either side were excluded). The other variables associated with that firm are not excluded.

\section{Estimation Results}

The estimation of equation (1) yields the following results:

\footnotetext{
${ }^{21}$ As in the standard empirical literature on firm investment, the dependent variable is normalized by fixed assets and some of the regressors are normalized by total assets. See Ramirez and Tan (2001) for an application to the case of Singapore corporates.
} 
- $\quad$ Tobin's Q and firm size are strongly positively correlated with investment (Table 4). The effect of Tobin's Q also holds if the shorter 2000-04 sample is used, or if a lagged value is used in the empirical model to avoid potential spurious contemporaneous correlations. ${ }^{22}$ The firm-size effect remains strong and statistically significant for several definitions of size, including dummy classifications (top $25^{\text {th }}$ percentile) or other size measures such as sales and market capitalization. ${ }^{23}$

- Cash flow and, to some extent, leverage also matter for investment. In particular, higher cash flow leads to higher investment ratios, indicating that the availability of internal sources of financing is important for investment decisions. Leverage appears to be negatively associated with investment, but its effect is statistically significant only in the case of GLCs. ${ }^{24}$

- Other variables do not seem to affect investment. The impact of sales on investment, while positive, is not statistically significant at the 5 percent level, suggesting a relatively weak accelerator effect. Corporate liquidity (proxied by the stock of cash and short-term securities) also does not have a statistically significant effect on investment.

- In general, the results in the baseline specification are robust, whether the full sample or the 2000-04 subperiod is used.

The effects of Tobin's Q and cash flow differ significantly according to the firm size group (Table 5). To shed light on the size effect on investment, the sample is split into three groups: (1) small firms (bottom $25^{\text {th }}$ percentile of the distribution of total assets); (2) medium firms (between the $25^{\text {th }}$ and $75^{\text {th }}$ percentiles); and (3) large firms (top $75^{\text {th }}$ percentile). While the role of Tobin's Q generally increases with size, by a factor of 3, the effect of cash flow is positive and statistically significant only for small firms. Also, for small companies, higher leverage has a negative effect on investment, indicating that, for these firms, insufficient financial restructuring may have been partly responsible for the sluggish recovery of investment during the post-Asian crisis period. Nevertheless, it is difficult to estimate the

\footnotetext{
${ }^{22}$ Despite the fact that the theoretical model suggests the use of contemporaneous Tobin's Q in the regression (Appendix I), lagged values of the regressors can be used to minimize potential endogeneity bias. This type of bias could arise if Tobin's Q and investment are determined jointly.

${ }^{23}$ A dummy for the top $25^{\text {th }}$ percentile in terms of market capitalization is used to control for very large firms. The estimations are also re-done with other measures of size. Results are robust to other measures, including the top $10^{\text {th }}$ percentile or top 50 firms, or including market valuation or other size measure ("unscaled") directly into the estimated regression. The whole sample is used to construct the size distribution, so that companies that have been present in the entire time span are slightly penalized if their asset valuation increased over time.

${ }^{24}$ The effect of leverage turns out to be the main difference in the investment behavior of GLCs compared with that of non-GLCs. The coefficient is significant and has a larger absolute value for GLCs, suggesting that deleveraging might significantly boost their investment.
} 
effect of leverage on investment, as it appears to have affected those companies in the two tails of the firm size distribution, in this case, the small firms and the very large ones (typically GLCs).

\section{Analysis by Sectors}

The determinants of investment are also analyzed for each sector. The results confirm the importance of firm size across sectors, while Tobin's Q matters for investment for firms in the industrial and consumer goods sectors, as well as in utilities, resources and conglomerates. Meanwhile, the roles of the accelerator effect and financing constraints vary substantially (Table 6). The findings for the 5 major sectors can be summarized as follows:

- In the industrial sector, the accelerator effect is strong and significant. The estimated impact of sales on investment is statistically significant and twice as large compared with the whole sample, suggesting that cyclical factors might be important for investment decisions. The effects of Tobin's Q and size remain important, while cash flow and liquidity are not statistically significant. The latter finding could reflect the fact that industrial companies may have easier access to external funds, being able to offer sizable fixed assets as collateral.

- The investment behavior of companies in utilities, resources, and conglomerates is somewhat similar to those in the industrial sector. The effect of Tobin's Q is positive and large (although it is estimated with a large standard error) and the size effect is also positive and statistically significant. The impact of sales is statistically significant, although it is smaller than in the case of the industrial sector. The negative effect of leverage on investment, while significant, is driven by the GLCs as mentioned above.

- In the services sector, the effects of cash flow and liquidity are positive and statistically significant. The size effect is also strong, indicating that large companies invest more. Meanwhile, Tobin's Q and sales are not statistically significant. These findings suggest that firms in the services sector, which are generally smaller in terms of fixed assets available as collateral, face more stringent constraints to outside financing.

- The investment behavior of IT companies is broadly similar to those in the services sector. First, cash flow is statistically significant and has a positive effect on investment. Meanwhile, Tobin's Q and sales do not seem to matter for investment. Finally, the size effect, while positive, is not statistically significant.

- In the case of consumer goods sector, the effects of size and Tobin's Q on investment are positive and statistically significant, while other factors, including cash flow and liquidity, do not seem to matter. 


\section{CONCLUding ReMARKS}

Following the Asian crisis, private investment in Malaysia collapsed and remains substantially below precrisis levels, despite the recovery since 2004. This collapse in investment coupled with a sluggish recovery and broadly stable savings rate has moved Malaysia's current account from a deficit into a substantial and widening surplus since the late 1990s.

The paper's main objective is to improve our understanding of the determinants of private investment and point to policy measures aimed at further strengthening the ongoing investment recovery. To that end, we establish some stylized facts and apply some standard empirical models of investment to both macroeconomic and corporate data. While the former helps identify the long-term macroeconomic trends, the latter allows us to assess the role of corporate sector profitability and other firm characteristics, as well as differences across sectors.

The aggregate data show a significant overinvestment in the years leading to the Asian crisis. The long-term relationship between investment and its macroeconomic determinants, points to overinvestment for about 4 years prior to 1998 exceeding 10 percent of GDP. The decline in investment following the Asian crisis in part reflects this overinvestment. In addition, the estimates indicate that the adjustment process is slow, suggesting that periods of over- and underinvestment are not short-term phenomena. This may reflect the nature of excess investment, which appears to have been concentrated in the property sector with a more durable capital stock, and/or a shift in investor sentiment, including worsening perceptions of the investment climate.

Another main finding of this paper is that low corporate profitability reflected in Tobin's Q appears to have been a drag on private investment. Profitability has been low in Malaysia across all sectors studied, and has been lower than the average of emerging market economies in the region. Furthermore, low market valuation indicators (including Tobin's Q and price-earnings ratio) indicate that the market expects low future profitability, which could further contribute to the sluggishness of investment. While a comprehensive study of the determinants of corporate profitability is beyond the scope of this paper, it may be a promising avenue for future research. Meanwhile, higher cash flow has a positive impact on investment, indicating that the availability of internal funds matter for investment decisions. There is some evidence of the effects of corporate financial restructuring on investment.

The empirical results also reveal differences in investment behavior across sectors and groups of firm size. For instance, while higher sales lead to higher investment in the case of the industrial sector, this effect is relatively weak in other sectors. Meanwhile, cash flow and liquidity are particularly relevant for investment in the services sector, pointing to financing constraints, perhaps consistent with a limited scope for collateralizing assets in this sector. Regarding firm size, smaller companies' investment appears to depend relatively more on cash flow and liquidity, indicating that access to external financing may be more constrained for smaller firms. 
Overall, our findings suggest that addressing the worsening perceptions' of the investment climate and enhancing prospects for profitability at the corporate level are critical for sustaining the ongoing recovery of private investment. The analysis of the long-term trends indicates, however, that a return to precrisis investment levels appears neither desirable nor necessary for securing Malaysia’s growth prospects. 
Table 1. Malaysia: Nonfinancial Corporate Sector Soundness Indicators, 1995-2004 1/

\begin{tabular}{|c|c|c|c|c|c|c|c|c|c|c|}
\hline & 1995 & 1996 & 1997 & 1998 & 1999 & 2000 & 2001 & 2002 & 2003 & 2004 \\
\hline \multicolumn{11}{|l|}{ Leverage and debt structure } \\
\hline Debt to equity & 31.6 & 47.0 & 58.6 & 54.4 & 40.1 & 30.7 & 29.7 & 27.6 & 30.3 & 32.2 \\
\hline Debt to assets & 17.3 & 23.3 & 26.0 & 29.0 & 25.2 & 21.5 & 22.4 & 22.2 & 21.0 & 21.9 \\
\hline Short-term debt to total debt & 74.1 & 61.4 & 61.2 & 66.6 & 70.5 & 79.6 & 77.4 & 75.0 & 72.8 & 67.9 \\
\hline \multicolumn{11}{|l|}{ Liquidity indicators } \\
\hline Current ratio 2/ & 1.4 & 1.3 & 1.3 & 1.2 & 1.4 & 1.4 & 1.5 & 1.6 & 1.6 & 1.7 \\
\hline Quick ratio 3/ & 0.9 & 1.0 & 0.9 & 0.8 & 0.9 & 0.9 & 1.0 & 1.1 & 1.1 & 1.2 \\
\hline Interest coverage ratio 4/ & 8.3 & 5.7 & 4.0 & 1.6 & 1.9 & 3.9 & 3.6 & 4.0 & 4.2 & 4.5 \\
\hline \multicolumn{11}{|l|}{ Profitability indicators } \\
\hline Operating margins (in percent) 5/ & 12.2 & 12.3 & 11.5 & 6.3 & 7.1 & 7.8 & 5.9 & 6.6 & 6.5 & 5.9 \\
\hline Return on equity (annual) & 12.3 & 11.8 & 8.9 & 2.6 & 7.3 & 6.8 & 5.8 & 5.6 & 5.8 & 6.2 \\
\hline Return on assets (annual) & 8.5 & 8.7 & 6.1 & 2.3 & 4.0 & 3.2 & 2.8 & 3.3 & 3.7 & 4.0 \\
\hline \multicolumn{11}{|l|}{ Valuation } \\
\hline Price to earnings ratio & 19.9 & 23.8 & 12.4 & 7.1 & 7.7 & 8.8 & 7.6 & 7.1 & 8.9 & 10.2 \\
\hline Tobin's Q & 1.5 & 1.7 & 1.0 & 0.7 & 0.9 & 0.8 & 0.7 & 0.7 & 0.8 & 0.8 \\
\hline \multicolumn{11}{|l|}{ Memorandum item: } \\
\hline Number of companies & 241 & 289 & 320 & 329 & 367 & 555 & 683 & 756 & 784 & 783 \\
\hline
\end{tabular}

Sources: WorldScope; and IMF staff calculations.

1/ Medians.

2/ Current assets to current liabilities.

3/ Cash and receivables to current liabilities.

4/ Operating earnings (EBIT) to gross interest expenses.

5/ Operating earnings (EBIT) in percent of sales. 
Table 2. Unit Root Tests 1/

\begin{tabular}{llc}
\hline & Levels & First Difference \\
\hline Real GDP & -0.871783 & $-4.664675 * * *$ \\
Real private fixed capital formation & -1.447633 & $-4.171621^{* * *}$ \\
Real public fixed capital formation & -1.032741 & $-3.502176^{* *}$ \\
Market capitalization & -1.877726 & $-4.691193 * * *$ \\
Private credit 2/ & $-3.598362 * *$ & - \\
Capital cost & $-3.173095 * *$ & - \\
Real lending rate & $-2.6158493 /$ & - \\
Exchange rate volatility & $-4.298097 * * *$ & - \\
\hline
\end{tabular}

1/ Augmented Dickey Fuller tests. ***, **, * mean rejection of the null hypothesis of a unit root at a 1,5 , and 10 percent confidence level, respectively.

Lag length is chosen based on Schwarz information criterion.

2/ Includes trend.

3/ Dickey-Fuller-GLS test rejects unit root at 5 percent confidence level.

Table 3. Vector Error Correction Models

\begin{tabular}{|c|c|c|c|c|c|c|c|c|}
\hline Dependent variable: Real private fixed ca & $\begin{array}{l}\text { mation } \\
\text { (1) }\end{array}$ & (2) & (3) & (4) & (5) & (6) & (7) & (8) \\
\hline \multicolumn{9}{|l|}{ Cointegrating equation } \\
\hline Real private fixed capital formation & 1.000 & 1.000 & 1.000 & 1.000 & 1.000 & 1.000 & 1.000 & 1.000 \\
\hline Real GDP & $\begin{array}{l}-1.023 \\
(-6.17)\end{array}$ & $\begin{array}{l}-1.096 \\
(-4.82)\end{array}$ & $\begin{array}{l}-1.074 \\
(-5.01)\end{array}$ & $\begin{array}{l}-1.129 \\
(-7.99)\end{array}$ & $\begin{array}{l}-1.125 \\
(-8.25)\end{array}$ & $\begin{array}{l}-1.180 \\
(-8.07)\end{array}$ & $\begin{array}{l}-0.517 \\
(-1.80)\end{array}$ & $\begin{array}{l}-1.078 \\
(-5.03)\end{array}$ \\
\hline Constant & 1.79 & 2.13 & 2.03 & 2.282 & 2.259 & 2.514 & -0.656 & 2.046 \\
\hline \multicolumn{9}{|l|}{ Short-run factors } \\
\hline Error correction term & $\begin{array}{l}-0.165 \\
(-3.28)\end{array}$ & $\begin{array}{l}-0.114 \\
(-2.28)\end{array}$ & $\begin{array}{l}-0.111 \\
(-2.41)\end{array}$ & $\begin{array}{l}0.072 \\
(0.74)\end{array}$ & $\begin{array}{r}0.049 \\
(0.57)\end{array}$ & $\begin{array}{l}0.019 \\
(0.19)\end{array}$ & $\begin{array}{l}-0.128 \\
(-2.99)\end{array}$ & $\begin{array}{l}-0.124 \\
(-2.27)\end{array}$ \\
\hline$\Delta$ (Real private fixed capital formation) & $\begin{array}{l}-0.201 \\
(-0.58)\end{array}$ & $\begin{array}{l}-0.283 \\
(-1.22)\end{array}$ & $\begin{array}{l}-0.345 \\
(-1.40)\end{array}$ & $\begin{array}{l}-0.215 \\
(-0.97)\end{array}$ & $\begin{array}{l}-0.122 \\
(-0.54)\end{array}$ & $\begin{array}{l}-0.289 \\
(-1.23)\end{array}$ & $\begin{array}{l}-0.355 \\
(-1.38)\end{array}$ & $\begin{array}{l}-0.195 \\
(-0.76)\end{array}$ \\
\hline$\Delta$ (Real GDP) & $\begin{array}{l}3.794 \\
(1.95)\end{array}$ & $\begin{array}{l}3.709 \\
(2.89)\end{array}$ & $\begin{array}{l}4.182 \\
(2.93)\end{array}$ & $\begin{array}{l}2.902 \\
(2.27)\end{array}$ & $\begin{array}{l}2.267 \\
(1.71)\end{array}$ & $\begin{array}{l}3.824 \\
(2.96)\end{array}$ & $\begin{array}{l}4.640 \\
(3.03)\end{array}$ & $\begin{array}{l}3.439 \\
(2.59)\end{array}$ \\
\hline Crisis dummy & -- & $\begin{array}{l}-0.870 \\
(-5.98)\end{array}$ & $\begin{array}{l}-0.905 \\
(-5.87)\end{array}$ & $\begin{array}{l}-0.957 \\
(-6.68)\end{array}$ & $\begin{array}{l}-0.956 \\
(-6.95)\end{array}$ & $\begin{array}{l}-0.717 \\
(-3.21)\end{array}$ & $\begin{array}{l}-0.714 \\
(-4.05)\end{array}$ & $\begin{array}{l}-0.881 \\
(-5.97)\end{array}$ \\
\hline$\Delta$ (Real public fixed capital formation) & -- & -- & $\begin{array}{l}-0.190 \\
(-0.78)\end{array}$ & -- & -- & -- & -- & -- \\
\hline Real lending rate & -- & -- & -- & $\begin{array}{l}-0.0891 / \\
(-1.99)\end{array}$ & $\begin{array}{l}-0.015 \\
(-2.38)\end{array}$ & -- & -- & -- \\
\hline Exchange rate volatility & -- & -- & -- & -- & -- & $\begin{array}{l}-0.029 \\
(-0.90)\end{array}$ & -- & -- \\
\hline$\Delta$ (Market capitalization) 2/ & -- & -- & -- & -- & -- & -- & $\begin{array}{l}0.001 \\
(1.17)\end{array}$ & -- \\
\hline$\Delta$ (Credit ratio) & -- & -- & -- & -- & -- & -- & -- & $\begin{array}{l}-0.006 \\
(-0.84)\end{array}$ \\
\hline Constant & $\begin{array}{l}-0.188 \\
(-1.64)\end{array}$ & $\begin{array}{l}-0.151 \\
(-1.98)\end{array}$ & $\begin{array}{l}-0.162 \\
(-2.07)\end{array}$ & $\begin{array}{l}0.053 \\
(0.43)\end{array}$ & $\begin{array}{r}0.030 \\
(0.30)\end{array}$ & $\begin{array}{r}-0.125 \\
(1.53)\end{array}$ & $\begin{array}{l}-0.207 \\
(-2.36)\end{array}$ & $\begin{array}{l}-0.121 \\
(-1.43)\end{array}$ \\
\hline $\begin{array}{l}\text { Zero-restriction on } \\
\text { GDP adjustment coefficient }\end{array}$ & \multicolumn{7}{|c|}{ Zero-restriction on } & Yes \\
\hline Adj. R-squared & 17.4 & 64.1 & 63.5 & 67.9 & 69.7 & 63.8 & 73.1 & 63.6 \\
\hline
\end{tabular}

Note: T-statistics in parentheses.

1/ Real lending rate adjusted by investment goods deflator.

2/ For years 1980-2004 only. 
Table 4. Malaysia: Investment Equation 1/

\begin{tabular}{|c|c|c|}
\hline Variable & Coefficients & Standard Error \\
\hline Constant & $1.30 *$ & 0.27 \\
\hline Tobin’s Q & $1.81^{*}$ & 0.50 \\
\hline Cash flow & $0.03 *$ & 0.01 \\
\hline GLC dummy* debt-to-equity & $-0.18 *$ & 0.09 \\
\hline Size dummy ( $25^{\text {th }}$ Percentile) & $3.49 *$ & 0.49 \\
\hline
\end{tabular}

Sources: IMF staff estimates; and WorldScope.

1/ For readability, only selected variables—such as those referred to in the main text—are presented. Estimations are based on fixed effects, with robust covariance matrix. Sample period is $1995-2004$. An * denotes significance at 10 percent.

Table 5. Malaysia: Investment Equation—Size Groups 1/

\begin{tabular}{lccc}
\hline \multicolumn{1}{r}{ Size Group } & Coefficient on Tobin's Q & Coefficient on Cash Flow & Other Relevant Variables \\
\hline & & & \\
All & $1.81^{*}$ & 0.03 & size, sales \\
Small & $1.01^{*}$ & $0.03^{*}$ & leverage (-) \\
Medium & $4.43^{*}$ & $<0.00$ & sales \\
Large & $3.27^{*}$ & $<0.00$ & GLC dummy \\
\hline
\end{tabular}

Sources: IMF staff estimates; and WorldScope.

1/ For readability, only selected variables—such as those referred to in the main text—are presented. Estimations are based on fixed effects, with robust covariance matrix. Sample period is 1995-2004. An * denotes significance at 10 percent. 
Table 6. Malaysia: Investment Equation by Sector 1/

\begin{tabular}{|c|c|c|}
\hline Variable & Coefficients & Standard Error \\
\hline \multicolumn{3}{|c|}{ Industrial sector } \\
\hline Sales & $0.38 *$ & 0.02 \\
\hline Tobin’s Q & $2.60 *$ & 0.82 \\
\hline Cash flow & 0.02 & 0.03 \\
\hline Size dummy ( $25^{\text {th }}$ Percentile) & $3.50 *$ & 0.81 \\
\hline \multicolumn{3}{|c|}{ Services sector } \\
\hline Sales & 0.01 & 0.02 \\
\hline Tobin’s Q & 0.97 & 0.98 \\
\hline Cash flow & $0.04 *$ & 0.01 \\
\hline Liquidity & $0.24 *$ & 0.08 \\
\hline Size dummy ( $25^{\text {th }}$ Percentile) & $4.58 *$ & 1.03 \\
\hline \multicolumn{3}{|c|}{ IT sector } \\
\hline Sales & $<0.01$ & 0.05 \\
\hline Tobin’s Q & -1.81 & 2.01 \\
\hline Cash flow & $0.19 *$ & 0.10 \\
\hline Size dummy ( $25^{\text {th }}$ Percentile) & $4.48 *$ & 2.76 \\
\hline
\end{tabular}

Sources: IMF staff estimates; and WorldScope.

1/ For readability, only selected variables—such as those referred to in the main text-are presented. Estimations are based on fixed effects, with robust covariance matrix. Sample period is 1995-2004. An * denotes significance at 10 percent. 


\section{APPENDiX: A CANONICAL MODEL OF CORPORATE INVESTMENT}

\section{Perfect Capital Markets}

Consider the standard neoclassical model of investment with adjustment costs. The discussion below borrows freely from Hayashi (1982) and Caballero (1999). Assuming away agency issues, investment decisions (and firm decisions more generally) are based on maximizing shareholder's value:

$$
V\left(K_{i, t}, \theta_{i, t}\right)=\max E_{t} \sum_{s=t}^{\infty} \beta_{i}^{s}\left[\pi\left(K_{i, s}, \theta_{i, t}\right)-C\left(I_{i, s}, K_{i, s}\right)-p_{s} I_{i, s}\right]
$$

subject to the capital accumulation constraint,

$$
K_{i, s}=\left(1-d_{i}\right) K_{i, s-1}+I_{i, s}
$$

where $\mathrm{K}$ is the beginning-of-period capital stock, $\pi$ is the profit function, $\mathrm{I}$ is investment, $\mathrm{C}$ is the cost of adjustment function, $\mathrm{p}$ is the relative price of capital goods and $\mathrm{d}$ is the constant rate of depreciation. Note that capital resulting from investment is assumed to become productive within the year.

The first-order conditions with respect to investment leads to the familiar $\mathbf{Q}$ relationships:

$$
q_{i, t}=E_{t} \sum_{s=0}^{\infty} \beta_{i}^{s}\left(1-d_{i}\right)^{s}\left[\pi_{K}\left(K_{i, t+s}, \theta_{i, t+s}\right)-C_{K}\left(I_{i, t+s}, K_{i, t+s}\right)\right]
$$

and

$$
p_{t}+C_{I}\left(I_{i, t}, K_{i, t}\right)=q_{i, t}
$$

According to the first-order condition, the marginal Q, denoted here by q, is defined as the expected present value of profits from new fixed capital investment. This equation can also be derived from arbitrage arguments.

To obtain an estimable equation for investment, one must assume functional forms for the adjustment cost function C. As shown by Hayashi (1982), one convenient parameterization is

$$
C(I, K)=\frac{\eta}{2}(I / K-c)^{2} K
$$

where c and $\eta$ are firm-specific constants. In this case, average Q and marginal q coincide. Substituting out the adjustment cost function into the first order condition gives the following investment equation:

$$
(I / K)_{i, t}=\alpha_{i}+\beta Q_{i, t}+\varepsilon_{i, t}
$$


where the intercept depends on the constant in the adjustment cost function and $\beta=1 / \eta$. The regression residual can be interpreted as an optimization error. Several implicit assumptions are made to justify the equation above as an estimable equation, including those that allow average $\mathrm{Q}$ to be used instead of marginal q. These include perfect competition in the factor and product markets, homogeneity of capital goods, linear homogeneity of technologies for production and adjustment costs, and independence of financing and investment decisions.

\section{Imperfect capital markets}

In the case of imperfect capital markets, the investment equation needs to be augmented to account for informational and other frictions that may exist. For example, informational asymmetries between borrowers and lenders (in practice firms know more about the riskiness and profitability of their investment projects) could lead to a gap between the cost of external financing and internal financing. In terms of the estimated equation, Q alone cannot explain fluctuations in investment. In addition, investment should be correlated with the change in net worth (internal funds) for firms that face capital market imperfections. Other variables such as liquidity (proxied by cash flow) and size may also affect investment decisions if they affect the marginal cost of funds, holding investment opportunities constant.

In the case of imperfect markets, the appropriate specification becomes:

$$
(I / K)_{i, t}=\alpha_{i}+\beta Q_{i, t}+\gamma Z_{i, t}+\varepsilon_{i, t}
$$

Where $\mathrm{Z}$ is a vector of firm-specific variables containing, sales, to account for any accelerator effect at the firm-level, cash flow, to control for the fact that financially constrained firms finance their investment operations with internal funds, or simply to reflect changes in liquidity; stock of liquid assets (including cash), since these assets are convertible to cash to finance investment projects. 


\section{References}

Akkina, Krishna, and Mehmet Celebi, 2002, "The Determinants of Private Fixed Investment and the Relationship between Public and Private Capital Accumulation in Turkey," Pakistan Development Review, Vol. 41, No. 3, pp. 243-54.

Caballero, R., 1999, “Aggregate Investment” in Handbook of Macroeconomics (Amsterdam: Elsivier), J. Taylor and M. Woodford eds., pp. 813-62.

Calcagnini, Giorgio, and Enrico Saltari, 2003, "Labour and Financial Market Determinants of Investment Decisions in Europe,” EIFC Working Paper No. 03-26 (Rome: European Integration Financial Systems and Corporate Performance).

Campos, Nauro, and Jeffrey Nugent, 2003, “Aggregate Investment and Political Instability: An Econometric Investigation,” Economica, Vol. 70, pp. 533-49.

Collyns, Charles, and Abdelhak Senhadji, 2002, “Lending Booms, Real Estate Bubbles, and the Asian Crisis,” IMF Working Paper 02/20 (Washington: International Monetary Fund).

Ghura, Dhaneshwar, and Barry Goodwin, 2000, "Determinants of Private Investment: A Cross-Regional Empirical Investigation,” Applied Economics, Vol. 32, pp. 1819-29.

Hayashi, F., 1982, “Tobin’s Marginal $q$ and Average q: A Neoclassical Interpretation,” Econometrica, Vol. 50, pp. 213-224.

Hubbard, G., 1998, “Capital Market Imperfections and Investment,” Journal of Economic Literature, Vol. 36, pp.193-225.

Kannapiran, Chinna, 2001, "Determinants of Private Sector Investment in Papua New Guinea: An Error Correction Model Analysis,” Pacific Economic Bulletin, Vol. 16, No. 1, pp. 86-94.

Kolstad, Ivar, and Espen Villanger, 2004, "Determinants of Foreign Direct Investment in Services,” Chr. Michelsen Institute Working Paper WP 2004:2, (Bergen, CMI).

Mercerau, Benoit, 2005, “FDI Flows to Asia: Did the Dragon Crowd out the Tigers?” (unpublished; Washington: International Monetary Fund), April.

Naqvi, Naveed, 2002, “Crowding-In or crowding-Out? Modelling the Relationship between Public and Private Fixed Capital Formation Using Co-Integration Analysis: The Case of Pakistan 1964-2000,” Pakistan Development Review, Vol. 41, pp. 255-76.

Nicolas, Françoise, 2004, "Which Exchange-Rate Policy to Help Boost Foreign Direct Investment-Led Growth in ASEAN?” in Economic Integration and Multinational Investment Behaviour, ed. by Pierre-Bruno Ruffini (Northampton, Massachusetts: Edward Elgar), 2004, pp. 272-292. 
Oshikoya, Temitope, 1994, "Macroeconomic Determinants of Domestic Private Investment in Africa: An Empirical Analysis," Economic Development and Cultural Change, Vol. 42, No. 3, pp. 573-96.

Pelgrin, Florian, Sebastian Schich, and Alain de Serres, 2002, "Increases in Business Investment Rates in OECD Countries in the 1990s: How Much Can Be Explained by Fundamentals?” Economics Department Working Papers No. 237 (Paris:

Organization for Economic Co-operation and Development).

Putrajaya Committee, 2005, Catalyzing GLC Transformation to Advance Malaysia's Development_GLC Transformation Manual. Available via the Internet: http://www.pcg.gov.my/trans manual.asp

— 2005, Intensifying Performance Management—Blue Book. Available via the Internet: http://www.pcg.gov.my/trans manual.asp

Ramirez, C.D., and L.H. Tan, 2003, "Singapore Inc. Versus the Private Sector: Are Government-Linked Companies Different?” IMF Working Paper 03/156 (Washington: International Monetary Fund).

Robertson, Peter, 2000, "Diminished Returns? Growth and Investment in Asia," Economic Record, Vol. 76, pp. 343-53.

Song, Haiyan, Zinan Liu, and Ping Jiang, 2001, “Analyzing the Determinants of China’s Aggregate Investment in the Reform Period,” China Economic Review, Vol. 12, pp. 227-42. 